\title{
Long-term consequences of under-nutrition during suckling on glucose tolerance and lipoprotein profile in female and male rats
}

\author{
Iliana López-Soldado, Maria Angeles Munilla and Emilio Herrera* \\ Department of Biochemistry and Molecular and Cellular Biology, University San Pablo-CEU, E-28668 Boadilla del Monte, \\ Madrid, Spain
}

(Received 1 March 2006 - Revised 19 May 2006 - Accepted 3 August 2006)

\begin{abstract}
To determine the effect of under-nutrition during suckling in adults, at delivery female Sprague Dawley rats were allowed to lactate litters of either eight (controls) or sixteen pups each (large litter, LL). The amount of milk taken by LL pups was less than the controls and the concentration of triacylglycerols (TG) in the milk of the former was lower. The increase of both body weight and length in LL was lower than in the controls during suckling. At weaning, pups were allowed to eat ad libitum a standard diet and whereas at 20 months female body weight did not differ between LL and control rats, LL males weighed less than controls. Plasma NEFA were lower in male LL than in controls at 10 months, leptin at 10 and 16 months and TG and VLDL-TG at 20 months, with no differences in females. When 20 months old, lumbar and epididymal adipose tissue weights were lower in male LL than in controls, but not in females. The increase in plasma insulin after oral glucose load was lower in LL than in controls, both in males and females at 4 and 16 months, and only in males at 10 months, whereas the change in plasma glucose remained constant between the groups. Results indicate that both the pancreatic $\beta$-cell function and insulin sensitivity and adipose tissue metabolism are independently programmed as a consequence of under-nutrition during suckling, the effect being more manifest for males than for females.
\end{abstract}

Programming: Gender: Litter size: Adipose tissue: Insulin: Lipoproteins

The most prevalent form of nutritional disorder of children in developing countries is malnutrition, whereas in adults overweight is the most widespread. Epidemiological studies have linked low birth weight with impaired glucose tolerance, abnormalities in blood lipid concentrations and risk for CVD and obesity in adults (Ravelli et al. 1976; Lucas, 1991; Barker, 1995; Leon, 1998; Waterland \& Garza, 1999; Lauren \& the EURO-BLCS Study Group, 2003). These alterations have been attributed to a mechanism whereby at critical periods of fetal and early development certain metabolic processes are programmed in the organism to accommodate a particular level of nutrition throughout its life, thus providing a survival advantage (Lucas, 1991; Hales \& Barker, 1992). However, subsequent improvements in nutrition during adult life appear to be a major cause for these pathophysiological alterations.

In view of the shorter life span of animals and the possibility of controlling the genetic and environmental influences, several animal models of developmental programming have been applied to understand the specific mechanisms responsible for these phenomena (Armitage et al. 2004). Although studies in rats support the hypothesis that prenatal and early postnatal nutrition permanently affect glucose-insulin relationships (Passos et al. 2000; Waterland \& Garza, 2002), additional data are needed to determine whether long-term effects of perinatal malnutrition modifying the glucose-insulin relationship are also associated with altered lipid metabolism, which by itself could affect glucose tolerance and insulin sensitivity. This is, however, a necessary step towards understanding the significance of altered nutrition during the perinatal phase in human health and designing potential interventions to avoid or ameliorate their adverse consequences. Several strategies have been used to determine the response in restricting fetal and/or early postnatal growth as a consequence of transient nutritional conditions early in life. One strategy is the reduction of the protein content of the maternal diet during pregnancy, where a transitory period of increased insulin sensitivity, followed by no change and an impaired glucose tolerance with frank diabetes was found, depending on the age of the animals studied (Hales \& Ozanne, 2003). Changes in the quality of nutrition, without affecting the total energy intake during the immediate postnatal period, have also been shown to cause metabolic programming. An increase in carbohydrate-derived energy during suckling caused a sustained hyperinsulinaemia in adulthood without dietary intervention (Vadlamudi et al. 1993) and formed the basis for adult-onset obesity (Vadlamudi et al. 1995; Srinivasan et al. 2003). Another strategy was to adjust the litter size during lactation so that pups in small litters received more milk than those in larger litters. This was found to cause lifetime growth alterations (McCance, 1962; Plagemann et al. 1992) and both large and small litters were determined to have reduced pancreatic $\beta$-cell glucose-responsiveness when adults (Waterland \& Garza, 2002).

\footnotetext{
Abbreviations: AUC, area under the curve; LL, large litter; Ch, cholesterol; TG, triacylglycerol.

*Corresponding author: Dr. E. Herrera, fax +34 913510496, email eherrera@ceu.es
} 
Under-nutrition during the perinatal period could have longterm effects not only in the glucose and insulin axis but also in the level of circulating lipids in the offspring, but these two specific metabolic sites have not been previously evaluated in the same animals at different ages after food restriction during the suckling period, nor determining the differences in the gender response. The present study was therefore addressed to analyse these two metabolic sites at different ages in the same male and female animals after postnatal malnutrition in order to determine the potential interaction between them. Thus, by increasing litter size in rats during lactation we determined the long-term consequences of postnatal malnutrition on glucose-tolerance tests, plasma lipids and plasma lipoprotein profile.

\section{Materials and methods}

Female Sprague-Dawley rats from our animal quarters were housed under controlled light and temperature conditions $(12 \mathrm{~h}$ light-dark cycle; $22 \pm 1{ }^{\circ} \mathrm{C}$ ). Rats were mated when they weighed $180-190 \mathrm{~g}$ and fed ad libitum a purified diet containing the following per $\mathrm{kg}$ : $170 \mathrm{~g}$ casein; $100 \mathrm{~g}$ cellulose; $580 \mathrm{~g}$ maize starch; $100 \mathrm{~g}$ olive oil; $35 \mathrm{~g}$ salt mix; $10 \cdot 1 \mathrm{~g}$ vitamin mix. Other details of this diet composition and its characteristics have been previously reported (Amusquivar et al. 2000) and it was considered suitable as a control diet. The experimental protocol was approved by the Animal Research Committee of the University San Pablo-CEU. After delivery ( $24 \mathrm{~h}$ ), pups from the different dams were pooled and distributed at random in two groups, one of lactating dams with litters of eight pups each (controls) and the other one of lactating dams with litters of sixteen pups each (large litters, LL). They were maintained under these conditions until weaning (at $21 \mathrm{~d}$ ). From this time, female and male pups were separated in different cages and all the animals were fed ad libitum a standard non-purified diet (B\&K Universal, Barcelona, Spain). Milk yield was estimated from pup weight and weight gain on days 7-8 and days $15-16$ of lactation, as previously described (Sampson \& Jansen, 1984). On day 10 of lactation, after being separated from their litters, some dams were anaesthetized with a cocktail $(0.5 \mathrm{ml} / 200 \mathrm{~g}$ body weight $)$ containing $9 \mathrm{mg}$ ketamine (Imalgene 500; Rhone Merieux, Lyon, France) and 0.25 mg chlorpromazine (Largactil; Rhone Poulenc, Madrid, Spain) administered intraperitoneally. They were injected intraperitoneally with a solution of oxytocin $(0.25 \mathrm{ml} /$ $200 \mathrm{~g}$ body weight: 40 mg/l Syntocinón; Novartis Farmaceutica, Barcelona, Spain) and milk was obtained with gentle hand stripping of the teats. An aliquot of milk was immediately placed into chloroform-methanol (2:1, v/v) for lipid extraction (Folch et al. 1957) and once phospholipids had been eliminated with alumina in isopropylalcohol, samples were processed for the analysis of triacylglycerols (TG) (Sigma, St. Louis, MO, USA). Some rats from each group were decapitated at different ages and trunk blood collected into receptacles containing $1 \mathrm{~g} \mathrm{Na}_{2}$-EDTA/1 for plasma separation. Plasma was kept at $-80^{\circ} \mathrm{C}$ until analysed for glucose, TG, NEFA and immunoreactive insulin by commercial kits (Boehringer-Mannheim, Mannheim, Germany, Menarini Diagnostic, Florence Italy, Wako Chemical GmbH, Neuss, Germany and Mercodia AB, Uppsala, Sweden, respectively). Leptin was assayed by ELISA using a commercial kit specific for rat (DRG Diagnostics, Mountainside, NJ, USA). Liver, brain and periuterine, epididymal and lumbar adipose tissue were immediately dissected and weighed and aliquots of liver tissue were placed into liquid $\mathrm{N}$ and kept at $-80^{\circ} \mathrm{C}$ until analysis. Frozen liver aliquots were used for lipid extraction (Folch et al. 1957) and aliquots of lipid extracts were quantified for different lipid moieties after image analysis and separation by one-dimensional TLC (Ruiz \& Ochoa, 1997) using the G5-700 BIOIMAGE TLC scanner of Bio-Rad (Hercules, CA, USA). Spots were quantified as integrated optical densities against an internal standard of cholesterol formate and calibration curves of TG, cholesterol (Ch), esterified-Ch and fatty acids standards.

Oral glucose tolerance tests were performed as follows. All tests were conducted between 09.00 and 12.00 hours in overnight fasted rats. After collecting tail blood (0 time), rats received an oral load of $2 \mathrm{~g}$ glucose $/ \mathrm{kg}$ body weight and blood was collected from the tail at 7.5, 15, 22.5, 30 and $60 \mathrm{~min}$ and processed for plasma glucose and insulin determinations as earlier. Blood samples obtained at 0 time were also used for the analysis of plasma TG and NEFA, as earlier.

In rats killed at 20 months, plasma was used for VLDL separation by ultracentrifugation at $224000 \mathrm{~g}$ for $3 \mathrm{~h}$ at density $1.006 \mathrm{~kg} / \mathrm{l}$ in a Beckman TL-100 ultracentrifuge (Beckman Instruments, Madrid, Spain) with a Beckman TLA $100 \cdot 2$ rotor, as previously described (Munilla \& Herrera, 1997). Supernatant fractions were recovered by tube slicing whereas the remaining apoB-100 containing lipoproteins (mainly LDL) were precipitated in the infranatants by treatment with a mixture (10:1, by vol.) of $14 \mathrm{~mm}$-phosphotungstic acid and $2 \mathrm{~mm}$ $\mathrm{MgCl}_{2}$. After sitting for $24 \mathrm{~h}$ at $4{ }^{\circ} \mathrm{C}$, HDL were separated in the supernatant after centrifugation at $15000 \mathrm{rpm}$ for $5 \mathrm{~min}$. TG and $\mathrm{Ch}$ concentrations were determined by enzymatic methods with commercial kits (Menarini Diagnostics).

\section{Statistics}

All analyses were conducted in SPSS (version 14.0; Chicago, IL, USA). Results were expressed as means with their standard errors. ANOVA with repeated measures with Bonferroni correction for multiple comparisons was used to compare the group differences in plasma lipids, leptin levels and glucose tolerance tests at different ages. Differences between means were determined by two-way ANOVA with litter size and gender as the fixed factors; significant interactions by litter size or gender were then analysed by Student's $t$ test. Data where the variances were not equal were log-transformed prior to analysis. Differences between the two groups at $20 \mathrm{~d}$ old were analysed by Student's $t$ test.

\section{Results}

Body weight and length and metabolic variables during suckling

Whereas on the first day of age, body weight and body length of pups from LL (sixteen pups per litter) did not differ from controls (eight pups per litter), from day 5 until weaning (day 21) LL pups weighed less and were smaller than those from controls, the difference in both variables increasing as the pups got older (Fig. 1). Although total milk yield expressed as g per d was higher in dams with LL than controls, pups in the first group received significantly less amounts of milk per $d$ than those in 

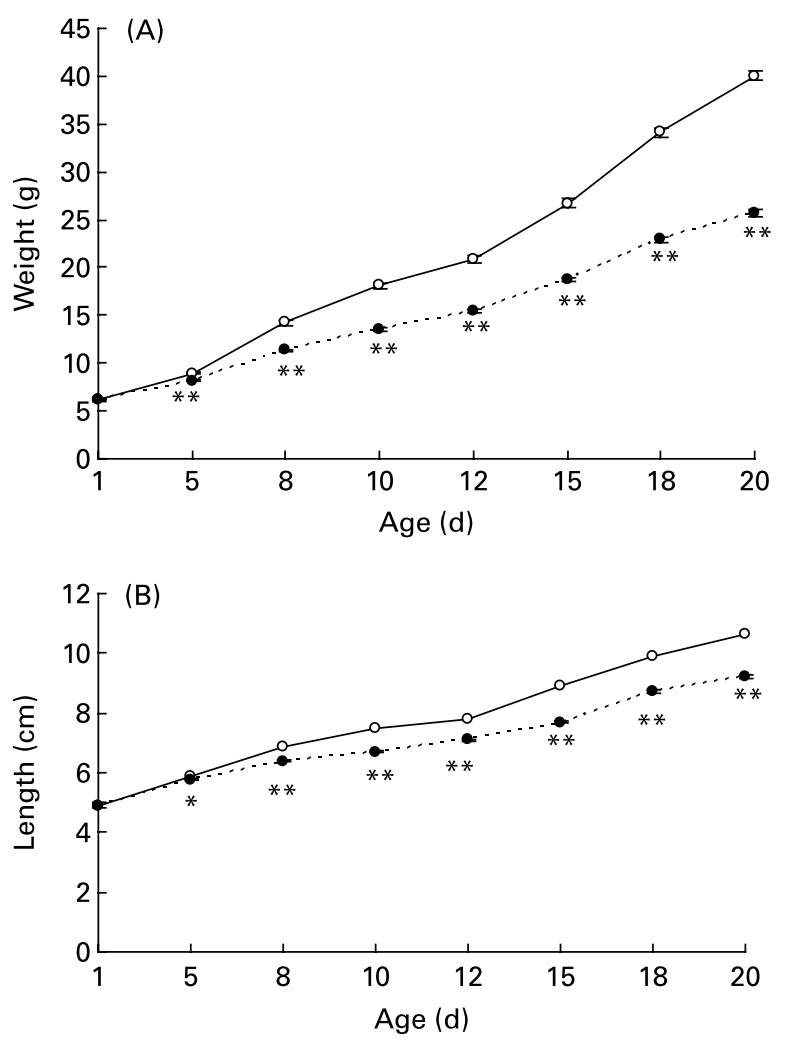

Fig. 1. Body weights $(A)$ and lengths $(B)$ during suckling in control $(-\bigcirc-)$ and large litter (LL; - - -) sizes. Values are means with their standard errors for ten to twenty-seven representative pups from each litter (day 1) and total number of pups (fifty-six to ninety-four; days 5-20). Mean values were significantly different between the two groups on the corresponding days: ${ }^{\star} P<0.05 ;{ }^{*} P<0.01$. For details of animals and procedures, see p. 1031.

the second at both day $8(2.79$ (SEM $0 \cdot 15) \mathrm{g} /$ pup per $\mathrm{d}$ in controls and 1.70 (SEM 0.05) in LL; $P<0.001$ ) and day 15 of lactation (4.01 (SEM 0.19) in controls and 2.56 (SEM 0.11) in LL; $P<0 \cdot 001)$. Milk TG concentration was also lower in dams of LL than in those of controls (552 (SEM 14) $\mu \mathrm{mol} / \mathrm{ml}$ in controls and 380 (SEM 36) in LL, $P<0 \cdot 01$ ).

At the end of the suckling period (day 20) lower body weight from LL rats was also accompanied by lighter liver and brain weights as well as lower plasma glucose, insulin, leptin and TG levels, with no difference in plasma NEFA and Ch levels nor in liver TG concentration compared with controls (Table 1).

\section{Body weight and metabolic variables at different ages after weaning}

Body weight in males progressively increased until 16 months, values being consistently lower in those from LL than from control rats (Fig. 2). A similar trend was also found in females and, although absolute values were always lower in females, body weight in female rats of the LL group was lower than in controls until age 16 months (Fig. 2). Plasma levels of TG in male rats were not significantly lower in LL rats at 4, 10 or 16 months (Table 2). In females, plasma TG levels did not differ between LL and control groups at 4, 10 and 16 months old, although there was also a tendency for them to be lower in LL than in controls. Plasma TG levels were lower in female than in male control rats at 10 months, and values at 16 months were always higher in both males and females as when the animals were younger. Plasma NEFA levels in males were lower in LL rats than in controls when they were 10 months old, the difference disappearing when they were 4 or 16 months old (Table 2). Unlike those found in males, plasma NEFA levels in females did not differ between the two groups at any of the time points studied, although values at 16 months were higher than in males. In males, there were no differences in plasma $\mathrm{Ch}$ levels between the two groups at 4 and 10 months old, but they were significantly lower in the LL group than in the controls at 16 months, whereas in females no difference between the two groups was found at any of the time points studied (Table 2). Plasma leptin levels were measured only in 10 and 16 month old males and in both cases values were significantly lower in those of the LL group than in controls (Table 2). In females, plasma leptin levels were measured only at 16 months, and although values were lower in LL than in control animals, the difference did not reach statistical significance.

Animals were killed at 20 months. At this age, body weight and size were lower in male LL than in male controls. This difference was not observed in females, the respective values of which were lower than in males (Table 3). Furthermore, in male liver, kidney, lumbar adipose tissue and epididymal fat pads, weights were lower in LL rats than in

Table 1. Tissue weights and metabolic variables in 20-d-old rats suckled in control and large litter (LL) sizes* (Values are means with their standard errors for six to seven rats per group)

\begin{tabular}{|c|c|c|c|c|c|}
\hline & \multicolumn{2}{|c|}{ Control } & \multicolumn{2}{|c|}{ LL } & \multirow[b]{2}{*}{ Statistical significance $P$} \\
\hline & Mean & SEM & Mean & SEM & \\
\hline Liver weight (g) & 1.43 & 0.09 & 0.85 & 0.06 & 0.000 \\
\hline Brain weight (g) & $1 \cdot 31$ & 0.03 & $1 \cdot 20$ & 0.04 & 0.043 \\
\hline Plasma glucose (mg/l) & 1581 & 28 & 1465 & 17 & 0.006 \\
\hline Plasma insulin (pm/ml) & $90 \cdot 6$ & $19 \cdot 8$ & $35 \cdot 4$ & $14 \cdot 4$ & 0.049 \\
\hline Plasma leptin (ng/ml) & $44 \cdot 0$ & $5 \cdot 6$ & $19 \cdot 9$ & 1.5 & 0.001 \\
\hline Plasma TG (mg/l) & 2214 & 140 & 1503 & 169 & 0.007 \\
\hline Plasma NEFA $(\mu \mathrm{M})$ & 551.9 & $13 \cdot 8$ & $380 \cdot 4$ & $35 \cdot 7$ & NS \\
\hline Plasma cholesterol (mg/l) & 1863 & 22 & 1959 & 153 & NS \\
\hline Liver TG ( $\mu \mathrm{mol} / \mathrm{g}$ tissue) & $67 \cdot 4$ & $2 \cdot 2$ & $59 \cdot 8$ & $15 \cdot 3$ & NS \\
\hline
\end{tabular}

${ }^{*}$ For details of animals and procedures, see p. 1031.

TG, triacylglycerol. 


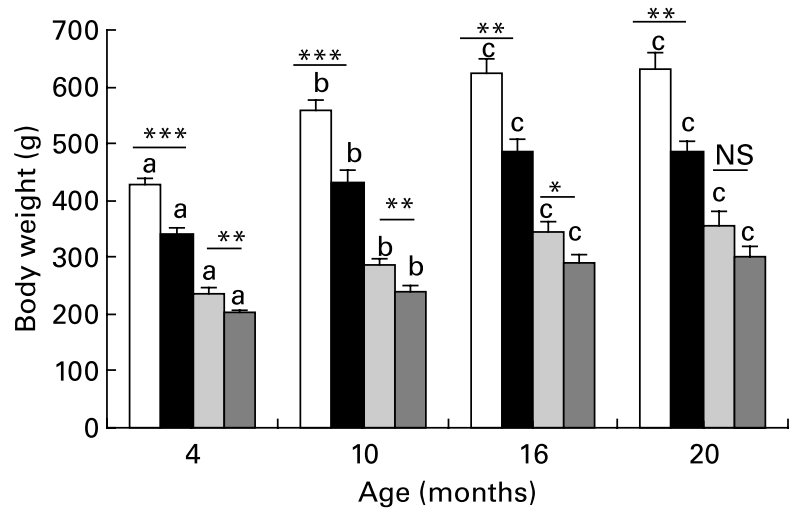

Fig. 2. Body weight in male control $(\square)$ and large litter (ם) and female (control $\square$ and large litter $\square$ ) size rats at different ages after weaning. Values are means with their standard errors for seven to twelve rats per group. $a, b, c$ Mean values with unlike superscript letters were significantly different and indicate statistical comparison over the entire study period $(P<0.05)$. Mean values were significantly different between control and $L L$ rats: ${ }^{\star} P<0.05 ;{ }^{\star \star} P<0.01 ;{ }^{\star \star \star} P<0.001$.

controls. These differences disappeared for liver and kidney weights when corrected by body weight, but they were maintained statistically lower for male LL than control rats in the case of lumbar adipose tissue and epididymal fat pads (Tables 3 and 4). The organ weights of 20-month-old females were lower than in males and they were similar for LL and control groups, the only significant difference being for kidney weight, which was lower in the LL group. No significant difference was found in absolute values when corrected by body weight for liver, kidney, lumbar adipose tissue or periuterine adipose tissue (Tables 3 and 4).

A lipoprotein profile was obtained in the 20-month-old rats. In males, plasma TG levels were lower in LL than in controls, this change mainly corresponding to those of VLDL, whose levels were lower in LL than in control groups, with no difference between the two groups in HDL-TG (Table 5). In males, plasma Ch levels were lower in 20-month-old LL rats than in controls, the difference mainly corresponding to LDL-Ch, with no differences in VLDL- or HDL-Ch. In 20-month-old females, no difference between LL and control groups was found in plasma TG, VLDL-TG or HDL-TG (Table 5). However, plasma Ch levels were higher in LL than in control female rats, this difference also appearing in both HDL- and LDL-Ch, with no difference in VLDL-Ch (Table 5).

A different trend between 20-month-old males and females was found in the distribution of liver lipid concentration. Whereas in males, the only change between LL and control rats appeared in a lower TG concentration in the former group, decreased concentrations of both $\mathrm{Ch}$ and esterified-Ch and an enhanced fatty acid concentration were found in liver of LL female rats compared with controls (Table 6).

\section{Oral glucose tolerance tests}

Basal plasma glucose and insulin levels (0 time) did not differ between LL and control rats at 4, 10 or 16 months (data not shown). However, major differences were found as a response to the oral glucose load. Values are expressed as the area under the curve (AUC) for both glucose and insulin during the $60 \mathrm{~min}$ of the test. It was found that the AUC for glucose in males at the age of 4,10 and 16 months was very stable and did not differ between LL and control rats (Table 7). However, the AUC for insulin in these same males progressively increased as they became older, values always being significantly lower in LL than in control rats (Table 7). In females, the AUC of glucose was very similar to that observed in males and it too was very stable with age, with no difference between LL and control rats. The AUC values for insulin in females tended to be consistently lower than those found in males. In female control rats, the AUC values for insulin did not increase with age, whereas in LL female rats, with the exception of 10-month-old females, values were significantly lower than those observed in the control group (Table 7).

\section{Discussion}

The present study consistently shows that under-nutrition during the suckling period due to LL size in rats causes a permanent reduction in glucose-stimulated insulin secretion despite a normal glucose tolerance, suggesting an enhanced insulin sensitivity. Although this finding may be related to the hypolipidaemia tendency in males, this is not, however, the case in females, suggesting that the endocrine pancreas was primarily programmed as result of the under-nutrition during suckling.

During suckling the reduced milk intake in LL rats is added to a reduction in TG concentration in milk, which is the most abundant lipid component in milk (Vilaró et al. 1987; Barbas \& Herrera, 1998) and therefore the main energy source for the suckling newborn. Other under-nutrition conditions such as that caused by a glucose-restricted diet during lactation have also been shown to decrease milk lipid concentration in rats (Lanoue \& Koski, 1994). This condition of decreased milk intake and lower milk TG content causes metabolic and endocrine disturbances in the suckling newborns, as shown here by decreased plasma glucose, TG, insulin and leptin concentrations. The leptin concentration is probably related to a decreased adipose tissue mass, as it coincides with the lower body weight of the pups, which was more noticeable than the reduced length of the LL animals. A blunted insulin secretion after a glucose stimulus and a lack of capacity to recover normal fat depots when LL animals are allowed to eat ad libitum standard rat chow from weaning seems to be programmed by the under-nutrition condition during suckling. The decreased $\beta$-cell response in LL rats when adults, confirms previous findings (Waterland \& Garza, 2002) and supports the hypothesis that the endocrine pancreas contributes to the programming in this model. Since the LL rats consistently exhibited normal glucose tolerance, the findings suggest increasing insulin sensitivity, which was maintained until the animals were 16 months old, when the last oral glucose tolerance test was performed, and corresponds to middle-age for the Sprague Dawley rat (Bassant et al. 1994; Barzilai \& Rossetti, 1996). Although this effect could be partially related to the hypolipidaemia indirectly derived from the decreased fat depot of the studied animals, this condition was only observed in males in the form of decreases in plasma NEFA levels at 10 months, and could result from a decreased lipolytic activity secondary to the enhanced insulin sensitivity. It was not observed in females, where the decreased insulin release after the oral glucose load was also impaired in the LL 
Table 2. Plasma lipid and leptin levels at different ages in rats suckled in control and large litter (LL) sizesł (Values are means with their standard errors for six to twelve rats per group)

\begin{tabular}{|c|c|c|c|c|c|c|}
\hline \multirow[t]{2}{*}{ Age (months) } & \multicolumn{2}{|c|}{4} & \multicolumn{2}{|c|}{10} & \multicolumn{2}{|c|}{16} \\
\hline & Mean & SEM & Mean & SEM & Mean & SEM \\
\hline \multicolumn{7}{|l|}{ Triacylglycerol (mg/l) } \\
\hline \multicolumn{7}{|l|}{ Male } \\
\hline Control & $958^{a}$ & 138 & $1110^{\mathrm{a}}$ & 83 & $1833^{\mathrm{b}}$ & 240 \\
\hline LL & $685^{\mathrm{a}}$ & 112 & $893^{\mathrm{ab}}$ & 104 & $1365^{b}$ & 152 \\
\hline \multicolumn{7}{|l|}{ Female } \\
\hline Control & $638^{a}$ & 73 & $630^{\mathrm{a}}+\dagger$ & 46 & $1687^{\mathrm{b}}$ & 276 \\
\hline LL & $494^{\mathrm{a}}$ & 71 & $668^{a b}$ & 59 & $1439^{b}$ & 187 \\
\hline \multicolumn{7}{|l|}{ Significance of effect of: } \\
\hline Gender & \multicolumn{2}{|c|}{0.031} & \multicolumn{2}{|c|}{0.000} & \multicolumn{2}{|c|}{ NS } \\
\hline Litter size & \multicolumn{2}{|c|}{0.048} & \multicolumn{2}{|c|}{ NS } & \multicolumn{2}{|c|}{ NS } \\
\hline Litter size $\times$ Gender & \multicolumn{2}{|c|}{ NS } & \multicolumn{2}{|c|}{ NS } & \multicolumn{2}{|c|}{ NS } \\
\hline \multirow{2}{*}{\multicolumn{7}{|c|}{ NEFA $(\mu \mathrm{M})$}} \\
\hline \multicolumn{6}{|l|}{ Male } & \\
\hline Control & $1241^{a b}$ & 61 & $1391^{\mathrm{a}}$ & 27 & $1206^{b}$ & 36 \\
\hline LL & $1265^{\mathrm{a}}$ & 108 & $1204^{a_{*}}$ & 60 & $1220^{\mathrm{a}}$ & 60 \\
\hline \multicolumn{7}{|l|}{ Female } \\
\hline Control & $1129^{a}$ & 99 & $1313^{\mathrm{a}}$ & 38 & $1592^{\mathrm{a}} \dagger$ & 122 \\
\hline $\mathrm{LL}$ & $1048^{\mathrm{a}}$ & 82 & $1276^{\mathrm{ab}}$ & 33 & $1576^{\mathrm{b}}+\dagger$ & 97 \\
\hline \multicolumn{7}{|l|}{ Significance of effect of: } \\
\hline Gender & \multicolumn{2}{|c|}{ NS } & \multicolumn{2}{|c|}{ NS } & & \\
\hline Litter size & & & & & & \\
\hline Litter size $\times$ Gender & & & & & & \\
\hline Cholesterol (mg/l) & & & & & & \\
\hline Male & & & & & & \\
\hline Control & $769^{a}$ & 51 & $1120^{\mathrm{b}}$ & 51 & $1283^{\mathrm{c}}$ & 87 \\
\hline LL & $775^{\mathrm{a}}$ & 34 & $920^{\mathrm{b}}$ & 53 & $905^{a b_{* *}}$ & 67 \\
\hline Female & & & & & & \\
\hline Control & $840^{a}$ & 76 & $1023^{a b}$ & 35 & $1127^{\mathrm{b}}$ & 92 \\
\hline LL & $923^{a}$ & 57 & $1024^{a}$ & 49 & $1023^{a}$ & 74 \\
\hline Significance of effect of & & & & & & \\
\hline Gender & & & & & & \\
\hline Litter size & & & & & & \\
\hline Litter size $\times$ Gender & & & & & & \\
\hline Leptin (ng/ml) & & & & & & \\
\hline Male & & & & & & \\
\hline Control & & & $39 \cdot 4^{\mathrm{a}}$ & 3.9 & $81 \cdot 8^{a}$ & $18 \cdot 4$ \\
\hline LL & & & $19 \cdot 6^{a * *}$ & 1.0 & $29 \cdot 0^{a *}$ & $6 \cdot 3$ \\
\hline Female & & & & & & \\
\hline Control & & & & & $52 \cdot 0$ & 8.3 \\
\hline LL & & & & & $30 \cdot 6$ & 6.9 \\
\hline Significance of effect of & & & & & & \\
\hline Gender & & & & & & \\
\hline Litter size & & & & & & \\
\hline Litter size $\times$ Gender & & & & & & \\
\hline
\end{tabular}

${ }^{a, b, c}$ Mean values with unlike superscript letters within a row were significantly different and indicate statistical comparison over the entire study period $(P<0.05)$.

Mean values were significantly different from those for the control rats: ${ }^{\star} P<0.05 ;{ }^{\star \star} P<0.01$.

Mean values were significantly different from those for the male rats: $+P<0.05 ;+\dagger P<0.01$.

$\ddagger$ For details of animals and procedures, see p. 1031.

ND, not determined.

animals, although no differences in plasma NEFA levels could be detected. Additional studies are required to establish the intrinsic mechanism for the decreased insulin release and enhanced insulin sensitivity for glucose utilization in the LL rats.

The decreased fat depots and altered lipoprotein profile observed in the LL male rats and the minor changes in females deserve some comment. The underfeeding condition during suckling clearly impairs long-term body growth in males, with a lesser effect in females. By analysing the weight of different tissues, it can be concluded that this difference in males mainly corresponds to fat depots, since both lumbar fat and epididymal fat pads weighed less in LL rats than in controls, in both absolute values and after correcting by body weight. Since plasma leptin levels have normally been associated with adipose tissue mass (Considine, 1997; Ahima \& Flier, 2000), this difference in fat depots between male LL and control rats is further emphasized by the consistent lower plasma levels of their leptin. These reduced adipose tissue depots in adult LL males could be contributing to their enhanced insulin sensitivity, since it is known that removal of visceral fat prevents insulin resistance in rats (Gabriely et al. 2002). In fact, as the rats become older, a condition of insulin resistance develops, as is shown by the progressive increment of the AUC for insulin. In other words, as the animals become older, more insulin is required to maintain a normal glucose tolerance and this effect seems to be delayed in LL rats 
Table 3. Body and tissue weights in 20-month-old rats suckled in control and large litter (LL) sizesł (Values are means with their standard errors for seven to twelve rats per group)

\begin{tabular}{|c|c|c|c|c|c|c|c|c|c|c|c|c|}
\hline & \multicolumn{2}{|c|}{ Body wt (g) } & \multicolumn{2}{|c|}{ Body size $(\mathrm{cm})$} & \multicolumn{2}{|c|}{ Liver (g) } & \multicolumn{2}{|c|}{$\begin{array}{l}\text { Liver }(\mathrm{g} / 100 \mathrm{~g} \\
\text { body } \mathrm{wt})\end{array}$} & \multicolumn{2}{|c|}{ Kidney (g) } & \multicolumn{2}{|c|}{$\begin{array}{c}\text { Kidney } \\
\text { (g/100 g body } \\
\text { wt) }\end{array}$} \\
\hline & Mean & SEM & Mean & SEM & Mean & SEM & Mean & SEM & Mean & SEM & Mean & SEM \\
\hline \multicolumn{13}{|l|}{ Male } \\
\hline Control & 631.8 & $27 \cdot 2$ & $28 \cdot 2$ & 0.23 & $15 \cdot 51$ & 0.85 & 2.45 & 0.05 & 3.66 & 0.09 & 0.58 & 0.01 \\
\hline LL & $485 \cdot 4^{\star \star \star}$ & $19 \cdot 0$ & $26 \cdot 8^{\star *}$ & 0.38 & $11 \cdot 23^{\star \star}$ & 0.79 & $2 \cdot 29$ & 0.08 & $2 \cdot 92^{\star \star \star}$ & $0 \cdot 16$ & 0.60 & 0.02 \\
\hline \multicolumn{13}{|l|}{ Female } \\
\hline Control & $356 \cdot 2 \dagger+\dagger$ & 23.5 & 24.0††† & 0.59 & 7.39††† - - - & 0.55 & 2.07††† & 0.04 & $2 \cdot 17 \dagger \dagger \dagger$ & 0.12 & 0.63 & 0.05 \\
\hline LL & 301.8††† & $15 \cdot 7$ & 23.4††† & 0.23 & 6.49††† & 0.30 & $2 \cdot 16$ & 0.06 & $1.72^{\star \star}+\dagger \dagger$ & 0.01 & 0.58 & 0.03 \\
\hline \multicolumn{13}{|l|}{ Significance of effect of: } \\
\hline Gender & \multicolumn{2}{|c|}{0.000} & \multicolumn{2}{|c|}{0.000} & \multicolumn{2}{|c|}{0.000} & \multicolumn{2}{|c|}{0.000} & \multicolumn{2}{|c|}{0.000} & \multicolumn{2}{|c|}{ NS } \\
\hline Litter size & \multicolumn{2}{|c|}{0.000} & \multicolumn{2}{|c|}{0.02} & \multicolumn{2}{|c|}{0.002} & \multicolumn{2}{|c|}{ NS } & \multicolumn{2}{|c|}{0.000} & \multirow{2}{*}{\multicolumn{2}{|c|}{ NS }} \\
\hline Gender $\times$ Litter size & \multicolumn{2}{|l|}{ NS } & \multicolumn{2}{|c|}{ NS } & \multicolumn{2}{|c|}{0.035} & \multicolumn{2}{|c|}{ NS } & \multicolumn{2}{|l|}{ NS } & & \\
\hline
\end{tabular}

Mean values were significantly different from those for the control rats: ${ }^{\star} P<0.05 ;{ }^{* \star} P<0.01 ;{ }^{* \star \star} P<0.001$.

Mean values were significantly different from those for the male rats: $\dagger \dagger P<0.01 ; \dagger \dagger \dagger P<0.001$.

‡For details of animals and procedures, see p.1031.

Table 4. Tissue weights in 20-month-old rats suckled in control and large litter (LL) sizesł (Values are means with their standard errors for seven to twelve rats per group)

\begin{tabular}{|c|c|c|c|c|c|c|c|c|c|c|c|c|}
\hline & \multicolumn{2}{|c|}{$\begin{array}{l}\text { Lumbar adipose } \\
\text { tissue }(\mathrm{g})\end{array}$} & \multicolumn{2}{|c|}{$\begin{array}{c}\text { Lumbar } \\
\text { adipose tissue } \\
\text { (g/100 g body } \\
\text { wt) }\end{array}$} & \multicolumn{2}{|c|}{$\begin{array}{l}\text { Periuterine } \\
\text { adipose tissue } \\
\text { (g) }\end{array}$} & \multicolumn{2}{|c|}{$\begin{array}{c}\text { Periuterine } \\
\text { adipose tissue } \\
\text { (g/100 g body } \\
\text { wt) }\end{array}$} & \multicolumn{2}{|c|}{$\begin{array}{l}\text { Epididymal fat } \\
\text { pads }(\mathrm{g})\end{array}$} & \multicolumn{2}{|c|}{$\begin{array}{c}\text { Epididymal fat } \\
\text { pads }(\mathrm{g} / 100 \mathrm{~g} \\
\text { body } w \mathrm{t})\end{array}$} \\
\hline & Mean & SEM & Mean & SEM & Mean & SEM & Mean & SEM & Mean & SEM & Mean & SEM \\
\hline \multicolumn{13}{|l|}{ Male } \\
\hline Control & 17.56 & 3.08 & 2.65 & 0.37 & & & & & 11.78 & 1.44 & 1.81 & 0.18 \\
\hline LL & $5 \cdot 92^{\star \star}$ & 0.93 & $1 \cdot 20^{\star \star}$ & 0.18 & & & & & $5 \cdot 33^{* * *}$ & 0.86 & $1.07^{\star \star}$ & 0.14 \\
\hline \multicolumn{13}{|l|}{ Female } \\
\hline Control & $7.08+\dagger$ & 1.14 & 1.91 & 0.20 & $5 \cdot 12$ & 0.50 & 1.44 & 0.10 & & & & \\
\hline LL & 4.49 & 0.77 & 1.45 & 0.20 & 3.69 & 0.70 & $1 \cdot 18$ & 0.15 & & & & \\
\hline \multicolumn{13}{|l|}{ Significance of effect of: } \\
\hline Gender & \multicolumn{2}{|c|}{0.016} & \multicolumn{2}{|c|}{ NS } & \multirow{3}{*}{\multicolumn{2}{|c|}{ NS }} & \multirow{3}{*}{\multicolumn{2}{|c|}{ NS }} & \multirow{3}{*}{\multicolumn{2}{|c|}{0.001}} & \multirow{3}{*}{\multicolumn{2}{|c|}{0.01}} \\
\hline Litter size & \multirow{2}{*}{\multicolumn{2}{|c|}{$\begin{array}{c}0.005 \\
\text { NS }\end{array}$}} & \multirow{2}{*}{\multicolumn{2}{|c|}{$\begin{array}{c}0.004 \\
\text { NS }\end{array}$}} & & & & & & & & \\
\hline Gender $\times$ Litter size & & & & & & & & & & & & \\
\hline
\end{tabular}

Mean values were significantly different from those for the control rats: ${ }^{\star} P<0.05 ;{ }^{\star \star} P<0.01 ;{ }^{\star \star \star} P<0.001$.

Mean values were significantly different from those for the male rats: $\uparrow \dagger P<0.01 ; \uparrow \dagger \uparrow P<0.001$.

$\ddagger$ For details of animals and procedures, see p.1031.

Table 5. Plasma lipoprotein profile in 20-month-old rats suckled in control and large litter (LL) sizesł

(Values are means with their standard errors for seven to twelve rats per group)

\begin{tabular}{|c|c|c|c|c|c|c|c|c|c|c|c|c|c|c|}
\hline & \multicolumn{2}{|c|}{ TG (mg/l) } & \multicolumn{2}{|c|}{$\begin{array}{l}\text { VLDL-TG } \\
(\mathrm{mg} / \mathrm{l})\end{array}$} & \multicolumn{2}{|c|}{$\begin{array}{c}\text { HDL-TG } \\
(\mathrm{mg} / \mathrm{l})\end{array}$} & \multicolumn{2}{|c|}{ Cholesterol (mg/l) } & \multicolumn{2}{|c|}{$\begin{array}{l}\text { VLDL- } \\
\text { cholesterol } \\
\text { (mg/l) }\end{array}$} & \multicolumn{2}{|c|}{$\begin{array}{l}\text { HDL-choles- } \\
\text { terol (mg/l) }\end{array}$} & \multicolumn{2}{|c|}{$\begin{array}{l}\text { LDL-choles- } \\
\text { terol (mg/l) }\end{array}$} \\
\hline & Mean & SEM & Mean & SEM & Mean & SEM & Mean & SEM & Mean & SEM & Mean & SEM & Mean & SEM \\
\hline \multicolumn{15}{|l|}{ Male } \\
\hline Control & 1538 & 234 & 1068 & 147 & 130 & 9 & 771 & 51 & 706 & 51 & 330 & 25 & 405 & 44 \\
\hline LL & $752^{\star \star}$ & 95 & $538^{*}$ & 92 & 156 & 109 & $581^{*}$ & 54 & 569 & 54 & 374 & 49 & $171^{\star *}$ & 3.7 \\
\hline \multicolumn{15}{|l|}{ Female } \\
\hline Control & 1075 & 145 & 742 & 124 & $175 \dagger$ & 16 & $547 \dagger \dagger$ & 35 & 555 & 35 & 284 & 25 & 207†† & 28 \\
\hline LL & 1087 & 156 & 751 & 120 & 137 & 15 & $1052^{\star \star \star}+\dagger \dagger$ & 75 & 624 & 75 & $616^{\star \star} \dagger$ & 66 & $374^{\star} \dagger$ & 67 \\
\hline \multicolumn{15}{|l|}{ Significance of effect of: } \\
\hline Gender & \multicolumn{2}{|l|}{ NS } & \multicolumn{2}{|c|}{ NS } & \multicolumn{2}{|c|}{ NS } & \multirow{2}{*}{\multicolumn{2}{|c|}{$\begin{array}{l}0.035 \\
0.008\end{array}$}} & \multicolumn{2}{|c|}{ NS } & \multicolumn{2}{|c|}{0.024} & \multicolumn{2}{|c|}{ NS } \\
\hline Litter size & \multirow{2}{*}{\multicolumn{2}{|c|}{$\begin{array}{c}\text { NS } \\
0.05\end{array}$}} & \multirow{2}{*}{\multicolumn{2}{|c|}{$\begin{array}{l}\text { NS } \\
\text { NS }\end{array}$}} & \multirow{2}{*}{\multicolumn{2}{|c|}{$\begin{array}{c}\text { NS } \\
0.02\end{array}$}} & & & \multirow{2}{*}{\multicolumn{2}{|c|}{$\begin{array}{l}\text { NS } \\
\text { NS }\end{array}$}} & \multirow{2}{*}{\multicolumn{2}{|c|}{$\begin{array}{l}0.000 \\
0.001\end{array}$}} & \multirow{2}{*}{\multicolumn{2}{|c|}{$\begin{array}{c}\text { NS } \\
0.000\end{array}$}} \\
\hline Gender × Litter size & & & & & & & \multicolumn{2}{|l|}{0.000} & & & & & & \\
\hline
\end{tabular}

Mean values were significantly different from those for the control rats: ${ }^{\star} P<0.05 ;{ }^{* \star} P<0.01 ;{ }^{* \star \star} P<0.001$.

Mean values were significantly different from those for the male rats: $\uparrow P<0.05 ; \dagger \dagger P<0.01 ; \dagger \dagger \uparrow P<0.001$.

$\ddagger$ For details of animals and procedures, see p.1031.

TG, triacylglycerol. 
Table 6. Liver lipid component in 20-month-old rats suckled in control and large litter (LL) sizesł (Values are means with their standard errors for seven to twelve rats per group)

\begin{tabular}{|c|c|c|c|c|c|c|c|c|}
\hline & \multicolumn{2}{|c|}{$\mathrm{TG}(\mu \mathrm{mol} / \mathrm{g})$} & \multicolumn{2}{|c|}{$\begin{array}{l}\text { Fatty acids } \\
(\mu \mathrm{mol} / \mathrm{g})\end{array}$} & \multicolumn{2}{|c|}{ Cholesterol $(\mu \mathrm{mol} / \mathrm{g})$} & \multicolumn{2}{|c|}{$\begin{array}{l}\text { Esterified cholesterol } \\
(\mu \mathrm{mol} / \mathrm{g})\end{array}$} \\
\hline & Mean & SEM & Mean & SEM & Mean & SEM & Mean & SEM \\
\hline \multicolumn{9}{|l|}{ Male } \\
\hline Control & 21.01 & $2 \cdot 84$ & $1 \cdot 18$ & 0.16 & 5.99 & 0.52 & 1.45 & 0.17 \\
\hline LL & $14 \cdot 16^{*}$ & 1.49 & 1.06 & 0.17 & $6 \cdot 36$ & 0.61 & 1.53 & 0.12 \\
\hline \multicolumn{9}{|l|}{ Female } \\
\hline Control & $22 \cdot 29$ & 4.77 & 1.06 & 0.09 & $8.28 \dagger$ & 0.93 & 1.33 & 0.10 \\
\hline LL & 21.57 & 3.51 & $2 \cdot 22^{* *} \dagger$ & 0.41 & $3 \cdot 76^{\star \star \star}+\dagger$ & 0.35 & $0.56^{* \star *}+\dagger \dagger$ & 0.08 \\
\hline \multicolumn{9}{|l|}{ Significance of effect of: } \\
\hline Gender & \multicolumn{2}{|c|}{ NS } & \multicolumn{2}{|c|}{0.023} & \multicolumn{2}{|c|}{ NS } & \multicolumn{2}{|c|}{0.001} \\
\hline Litter size & \multicolumn{2}{|c|}{ NS } & \multicolumn{2}{|c|}{0.024} & \multicolumn{2}{|c|}{0.003} & \multicolumn{2}{|c|}{0.030} \\
\hline Gender $\times$ Litter size & \multicolumn{2}{|c|}{ NS } & \multicolumn{2}{|c|}{0.006} & \multicolumn{2}{|c|}{0.001} & \multicolumn{2}{|c|}{0.009} \\
\hline
\end{tabular}

Mean values were significantly different from those for the control rats: ${ }^{\star} P<0.05 ;{ }^{* \star} P<0.01 ;{ }^{* \star *} P<0.001$ Mean values were significantly different from those for the male rats: $\uparrow P<0.05 ; \dagger \dagger P<0.01 ; \dagger \dagger \dagger P<0.001$. $\ddagger$ For details of animals and procedures, see p. 1031.

TG, triacylglycerol.

compared with control rats, and in females as compared with males in both groups. In fact, whereas the AUC for glucose was kept stable in male and female rats of both the LL and control groups, the AUC for insulin was lower in LL than in the control groups, and in females than in male rats, although the differences did not reach statistical significance at certain time points (Table 7).

The greatly impaired capacity to build up fat depots in male LL rats could also be responsible for the hypolipidaemia seen in these animals when 20 months old. Decreased fat depots could be responsible for the persistent decline in plasma TG as well as the low liver TG concentration seen in LL males. The low lipid substrate for VLDL synthesis would reduce liver VLDL-TG production, which may explain the low plasma levels in these animals. However, this reasoning cannot be used to understand the changes in the lipoprotein profile observed in female LL rats, where in addition to unchanged plasma VLDL levels, a clear hypercholesterolaemia corresponding to both increased HDL- and LDL-Ch levels was developed. In these animals, adipose tissue depots are less impaired

Table 7. Glucose tolerance tests at different ages in 20-month-old rats suckled in control and large litter (LL) sizesł (Values are means with their standard errors for seven to twelve rats per group)

\begin{tabular}{|c|c|c|c|c|c|c|}
\hline \multirow[t]{2}{*}{ Age (months) } & \multicolumn{2}{|c|}{4} & \multicolumn{2}{|c|}{10} & \multicolumn{2}{|c|}{16} \\
\hline & Mean & SEM & Mean & SEM & Mean & SEM \\
\hline \multicolumn{7}{|c|}{ AUC for glucose (mg/dl per min) } \\
\hline \multicolumn{7}{|l|}{ Male } \\
\hline Control & $11873^{a}$ & 268 & $10765^{b}$ & 338 & $10397^{\mathrm{b}}$ & 219 \\
\hline LL & $11275^{a}$ & 289 & $10306^{a}$ & 446 & $10198^{a}$ & 759 \\
\hline \multicolumn{7}{|l|}{ Female } \\
\hline Control & $11716^{\mathrm{a}}$ & 439 & $9852^{\mathrm{b}}$ & 261 & $10749^{a b}$ & 651 \\
\hline LL & $11097^{a}$ & 593 & $10747^{a}$ & 504 & $10464^{a}$ & 630 \\
\hline \multicolumn{7}{|l|}{ Significance of effect of: } \\
\hline Gender & \multicolumn{2}{|c|}{ NS } & \multicolumn{2}{|c|}{ NS } & \multicolumn{2}{|c|}{ NS } \\
\hline Litter size & \multicolumn{2}{|c|}{ NS } & \multicolumn{2}{|c|}{ NS } & \multicolumn{2}{|c|}{ NS } \\
\hline Litter size $\times$ Gender & \multicolumn{2}{|c|}{ NS } & \multicolumn{2}{|c|}{ NS } & \multicolumn{2}{|c|}{ NS } \\
\hline \multicolumn{7}{|c|}{ AUC for insulin ( $\mathrm{pm} / \mathrm{ml}$ per min) } \\
\hline \multicolumn{7}{|c|}{ Male } \\
\hline Control & $14673^{a}$ & 2551 & $26086^{b}$ & 3975 & $34868^{b}$ & 3137 \\
\hline LL & $8305^{a^{\star}}$ & 1128 & $15439^{a b^{*}}$ & 2407 & $24120^{\mathrm{b}^{\star}}$ & 3188 \\
\hline \multicolumn{7}{|l|}{ Female } \\
\hline Control & $9931^{a}$ & 130 & $12461^{\mathrm{a}}+\dagger$ & 2132 & $20181^{a}+$ & 3795 \\
\hline LL & $6296^{a^{\star \star}}$ & 658 & $12613^{a}$ & 1778 & $9461^{\mathrm{a}^{\star}}+\dagger$ & 918 \\
\hline \multicolumn{7}{|l|}{ Significance of effect of: } \\
\hline Gender & \multicolumn{2}{|c|}{ NS } & \multicolumn{2}{|c|}{0.005} & \multicolumn{2}{|c|}{0.000} \\
\hline Litter size & \multicolumn{2}{|c|}{0.006} & \multicolumn{2}{|c|}{ NS } & \multicolumn{2}{|c|}{0.001} \\
\hline Litter size $\times$ Gender & \multicolumn{2}{|c|}{ NS } & \multicolumn{2}{|c|}{ NS } & \multicolumn{2}{|c|}{ NS } \\
\hline
\end{tabular}

AUC, area under the curve.

${ }^{\mathrm{a}, \mathrm{b}}$ Mean values within a row with unlike superscript letters were significantly different and indicate statistical comparison over the entire study period $(P<0.05)$

Mean values were significantly different from those for the control rats: ${ }^{*} P<0.05 ;{ }^{* *} P<0.01$.

Mean values were significantly different from those for the male rats: $\dagger P<0.05 ; \dagger \dagger P<0.01$.

‡For details of animals and procedures, see p. 1031. 
than those in males, allowing a normal production of VLDL, while liver Ch concentration is greatly reduced, probably as a consequence of enhanced liver production of HDL and/or decreased LDL uptake. A sexual dimorphism concerning those changes in lipoprotein liver production has been documented (Tessitore et al. 2000), and an inverse relationship between liver Ch concentration and plasma HDL levels has been reported previously in female rats (Munilla \& Herrera, 1997). This suggests either an enhanced liver production of HDL, which would cause a depletion of liver Ch content or an enhanced bile $\mathrm{Ch}$ excretion in the presence of an enhanced reverse $\mathrm{Ch}$ metabolism. Present data do not permit us to decide between these two possibilities.

In summary, under-nutrition during suckling permanently decreases glucose-stimulated insulin secretion in male and female rats without affecting glucose tolerance. Whereas in males, it greatly impairs fat depot accumulation and reduces VLDL-TG in adults, it does not affect fat depot accumulation in females and has a hypercholesterolaemic effect, mainly corresponding to increments in plasma LDL- and HDL-Ch levels.

\section{Acknowledgements}

We thank Milagros Morante for her excellent technical assistance, Brian Crilly for editorial help and José María Garrido for his valuable help in the care of the experimental animals. Supported by grants from Ministerio de Educación y Ciencia (SAF2004-05998), Universidad San Pablo-CEU (19/03) and European Community (specific RTD programme "Quality of Life and Management of Living Resources", QLK1-2001 00138, PeriLip).

\section{References}

Ahima RS \& Flier JS (2000) Leptin. Annu Rev Physiol 62, 413-437. Amusquivar E, Rupérez FJ, Barbas C \& Herrera E (2000) Low arachidonic acid rather than $\alpha$-tocopherol is responsible for the delayed postnatal development in offspring of rats fed fish oil instead of olive oil during pregnancy and lactation. J Nutr 130, $2855-2865$.

Armitage JA, Khan IY, Taylor PD, Nathanielsz PW \& Poston L (2004) Developmental programming of the metabolic syndrome by maternal nutritional imbalance: how strong is the evidence from experimental models in mammals? J Physiol 561, 355-377.

Barbas C \& Herrera E (1998) Lipid composition and vitamin E content in human colostrum and mature milk. J Physiol Biochem 54, 167-174.

Barker DJ (1995) The fetal and infant origins of disease. Eur J Clin Invest 25, 457-463.

Barzilai N \& Rossetti L (1996) Age-related changes in body composition are associated with hepatic insulin resistance in conscious rats. Am J Physiol Endocrinol Metab 270, E930-E936.

Bassant MH, Jazat FR \& Lamour YA (1994) Age-related alterations in local cerebral glucose utilization in the Sprague-Dawley rat. Neurodegeneration 3, 243-250.

Considine RV (1997) Weight regulation, leptin and growth hormone. Horm Res 48, Suppl. 5, 116-121.

Folch J, Lees M \& Sloane Stanley GH (1957) A simple method for the isolation and purification of total lipids from animal tissues. J Biol Chem 22, 24-36.
Gabriely I, Ma XH, Yang XM, Atzmon G, Rajala MW, Berg AH, Scherer P, Rossetti L \& Barzilai N (2002) Removal of visceral fat prevents insulin resistance and glucose intolerance of aging an adipokine-mediated process? Diabetes 51, 2951-2958.

Hales CN \& Barker DJ (1992) Type 2 (non-insulin-dependent) diabetes mellitus: the thrifty phenotype hypothesis. Diabetologia 35, 595-601.

Hales CN \& Ozanne SE (2003) For debate: Fetal and early postnatal growth restriction lead to diabetes, the metabolic syndrome and renal failure. Diabetologia 46, 1013-1019.

Lanoue L \& Koski KG (1994) Glucose-restricted diets alter milk composition and mammary gland development in lactating rat dams. J Nutr 124, 94-102.

Lauren L \& the EURO-BLCS Study Group (2003) Relationship between birth weight and blood lipid concentrations in later life: evidence from existing literature. Int J Epidemiol 32, 862-876.

Leon DA (1998) Fetal growth and adult disease. Eur J Clin Nutr 52, S72-S82.

Lucas A (1991) Programming by early nutrition in man. Ciba Found Symp 156, 38-50.

McCance RA (1962) Food growth and time. Lancet 2, 271-272.

Munilla MA \& Herrera E (1997) A cholesterol-rich diet causes a greater hypercholesterolemic response in pregnant than in nonpregnant rats and does not modify fetal lipoprotein profile. J Nutr 127, $2239-2245$.

Passos MCF, Ramos CF \& Moura EG (2000) Short and long term effects of malnutrition in rats during lactation on the body weight of offspring. Nutr Res 20, 1603-1612.

Plagemann A, Heidrich I, Gotz F, Rohde W \& Dorner G (1992) Obesity and enhanced diabetes and cardiovascular risk in adult rats due to early postnatal overfeeding. Exp Clin Endocrinol 99, $154-158$.

Ravelli GP, Stein M \& Susser M (1976) Obesity in young men after famine exposure in utero and early infancy. $N$ Engl J Med 295, $349-353$.

Ruiz JI \& Ochoa B (1997) Quantification in the subnanomolar range of phospholipids and neutral lipids by monodimension thin-layer chromatography and image analysis. J Lipid Res 38, 1482-1489.

Sampson DA \& Jansen GR (1984) Measurement of milk yield in the lactating rat from pup weight and weight gain. J Pediatr Gastroent Nutr 3, 613-617.

Srinivasan M, Laychock SG, Hill DJ \& Patel MS (2003) Neonatal nutrition: metabolic programming of pancreatic islets and obesity. Exp Biol Med 228, 15-23.

Tessitore L, Batetta B, Vizio B, Mulas MF, Marengo B \& Dessi S (2000) Cell cholesterol esters and high-density lipoprotein plasma levels during liver hyperplasia in choline-fed male and female rats. Int J Exp Pathol 81, 241-248.

Vadlamudi S, Hiremagalur KB, Tao S, Kalhan SC, Kalaria RN, Kaung HC \& Patel MS (1993) Long-term effects on pancreatic functions of feeding a $\mathrm{HC}$ formula to rats during the preweaning period. Am J Physiol Endocrinol Metab 265, E565-E571.

Vadlamudi S, Kalhan SC \& Patel MS (1995) Persistence of metabolic consequences in the progeny of rats fed a $\mathrm{HC}$ formula in their early postnatal life. Am J Physiol Endocrinol Metab 269, E731-E738.

Vilaró S, Vinas O, Remesar X \& Herrera E (1987) Effects of chronic ethanol consumption on lactational performance in rat: mammary gland and milk composition and pups' growth and metabolism. Pharmacol Biochem Behav 27, 333-339.

Waterland RA \& Garza C (1999) Potential mechanisms of metabolic imprinting that lead to chronic disease. Am J Clin Nutr 69, 179-197.

Waterland RA \& Garza C (2002) Early postnatal nutrition determines adult pancreatic glucose-responsive insulin secretion and islet gene expression in rats. $J$ Nutr 132, 357-364. 